\title{
CORRELATION OF KNOWLEDGE, ATTITUDE, AND HEALTHY BEHAVIOR AMONG CHILDREN WITH AUTISM IN YOGYAKARTA
}

\author{
Hanna Wijaya1), Maria Meiwati Widagdo²), \\ Slamet Sunarno Harjosuwarno2) \\ 1)Faculty of Medicine, Universitas Kristen Duta Wacana, Yogyakarta \\ 2)Department of Public Health, Faculty of Medicine, \\ Universitas Kristen Duta Wacana, Yogyakarta
}

\begin{abstract}
Background: Over the past two decades, autism has emerged as a major public health concern in Indonesia. Although known for more than fifty years as one of the most severe childhood neuropsychiatric disorders, it was thought to be quite rare. Individuals with autism have impairments in social interaction and communication and exhibit some rote or repetitive, often self-stimulatory, behavior. In each of these dimensions, the impairment can range from mild to profound. This study aimed to determine the correlation between knowledge, attitude, and healthy behavior among children with autism in Yogyakarta.

Subjects and Method: This was a mixed study conducted at SLB Autis Bina Anggita, Yogyakarta. A total of 13 key informants including children with autism, teachers, and parents. The dependent variable was healthy behavior. The independent variables were knowledge and attitude. The data were collected by indepth interview and questionnaire. Quantitative data were analyzed by Spearman correlation.

Results: 11 of 13 children with autism had good knowledge about autism. All children had good attitude and health behavior. The correlations of knowledge, attitude, and health behavior were not statistically significant.

Conclusion: The correlations of knowledge, attitude, and health behavior are statistically non-significant.

Keywords: knowledge, attitude, health behavior, children, autism.

\section{Correspondence:}

Hanna Wijaya. Faculty of Medicine, Universitas Kristen Duta Wacana, Jl. Dr. Wahidin Sudiro Husodo No. 5-25, Yogyakarta 55224.

Email: hannwijaya@yahoo.com. Mobile: 081223787878.
\end{abstract}

The 4th International Conference on Public Health

Best Western Premier Hotel, Solo, Indonesia, August 29-30, 2018 | 142 https://doi.org/10.26911/theicph.2018.02.23 